\title{
MECHANICAL FAILURE ANALYSIS OF A RAKE UNLOADING SYSTEM USING FTA AND FMECA
}

\section{ALOK KUMAR SINGH \& SANDEEP MONDAL}

Department of Management Studies, IIT(ISM), India

Iron and Steel industries, raw materials are mostly transported, through the railway rakes. The railway provides some stipulated free time, for unloading the rakes and charges a penalty for the delay beyond the free time. This penalty charge increases the cost of the final products. This paper discusses the mechanical failure problem, which is the major cause of the delay in the unloading process, using Fault Tree Analysis (FTA) and Failure Mode Effect and Criticality Analysis (FMECA), to find the critical component of the failure, which helps the management to minimize the breakdowns.

KEYWORDS: Rake Unloading System, Mechanical Failure, FTA \& FMECA
\end{abstract}

Received: Aug 22, 2017; Accepted: Sep 12, 2017; Published: Sep 23, 2017; Paper Id.: IJMPERDOCT201725

\section{INTRODUCTION}

In Iron and Steel companies, the Raw Material Handling System (RMHS) is very vital part of the organization, as the production cost of such companies is directly associated with the efficiency of the raw material handling process. The efficiency of the RMHS greatly depends on the uninterrupted unloading process of the railway rakes, consisting of 58 or 59 numbers of wagons, that are used to transport raw materials like Iron Ore, Coal, etc. The railway provides 8 hours of free time to unload the rakes and if the unloading process exceeds the given free time, it leads to overhead on the company, in terms of penalty/demurrage cost, which indeed increases the unit cost of the raw materials. Consequently, there emerged a need for the analysis of the delay time of the rake unloading system. In this paper, the RMHS department of the selected Iron and Steel Company has been studied and tried to find out the various causes of delay time in the rake unloading process. Besides, the mechanical failure in the unloading process has been highlighted and explored rigorously to find its critical reason.

In literature, some studies have been carried out for different industries to figure out the root causes of the failure or delay in different sectors. Brito et al. [1] used a discrete event simulation and Multi-Criteria Decision Analysis for planning and sizing the logistics and production elements of a steel plant. Mukherjee et al. [2] Discussed the model for reducing the demurrage cost for inward rakes through material reallocation in a steel industry; they also suggested some corrective measures to reduce the delay. Dongre et al. [3] discussed the considerations for material flow design problems (i.e. Material handling equipment selection, flow path design, facility layout design, routing, etc.). Mukherjee et al. [4] have discussed an approach for inbound logistics capacity design by uncovering the hidden capacities of a raw material handling system in the steel industries. They claim that their study may maximize the utilization of unloading equipment, address system wide congestion and bottlenecks and better the route layout resulting in releasing capacity while promoting seamless material flow. 
They have recommended changes in operational procedures, rearrangement of rake scheduling mechanisms, redesigned route network and equipment layout coupled with a modest addition of unloading capacity. The use of data exploration is also reported for fault diagnosis in condition monitoring signal data, for instance, in vibration signal data collected through sensors attached to mechanical drives [5-6]. Sharma et al. Developed methodology for system failure behavior and maintenance decision making, policy [7]. Recently, Srivastava et al. [8] proposed a new methodology for developing maintenance policy using failure mode effect and criticality analysis (FMECA) method and Non Homogeneous Poisson Process (NHPP) models to identify the critical component and for deciding maintenance policy of an overhead crane in a steel manufacturing company. They also develop, a predictive maintenance policy using modified FMECA technique which is validated using the example of coal pulverizing mill [9]. In 2012 and 2013, FTA method was used in the analysis of failure rate and safety diagnosis on coal mine production systems, roof fall accidents in coal mines, main causes of accidents due to a gas outburst in mines, safety of rail transport systems in coal mine, effect of operating environment conditions on LHD, and radiation hazards in uranium mine [10-12].

After consideration of the FTA and FMECA applications, the need for data-oriented approach for enhancing decision support for delay time analysis is imperative. Therefore, this need motivates the data exploration methodology reported in our study. The research has been carried out based on a comprehensive study of the Rake-In/Out process with continuous work sampling and varied past data collected from the log books of the RMHS department of the selected company.

\section{BRIEF DESCRIPTION OF RAKE UNLOADING SYSTEM}

All incoming rakes are received by the traffic department from the railway, then the traffic department releases the brakes of each wagon manually and the rake is placed at the unloading station by plant internal locos and handed over to the RMHS department. The RMHS Department starts the unloading activity by performing the following activity:

- First the wagon is uncoupled manually from the rake and place it on the tippler table by the Side Aram Charger (SAC).

- It is then unloaded by a rotary type Wagon Tippler and material from the wagon falls on the two underground hoppers and through a series of conveyor, the material is stacked in their respective place by the Twin Boom Stacker (TBS).

- Empty wagon is then pushed to post tippling yard by the SAC, simultaneously next wagon is placed on the table.

- In the post tippling yard, the activity of wagon cleaning is carried out manually. Material left after unloading of wagon through rotary type wagon tippler is cleared in the post tippling area. The traffic people then make reformation of rake by coupling of wagon with each other.

- $\quad$ These activities are repeated until all the wagons are unloaded.

- Once unloaded, the concerned department handed over the information to the traffic department and the traffic department informs the railway regarding the completion of unloading. 


\section{METHODOLOGY AND RESULTS}

Here, a case example of a specific integrated Iron and Steel Company has been taken to perform a detailed analysis of the delay time for unloading process of the railway rakes which is used for raw materials, transportation so that a company may reduce the delay time which indeed decreases the demurrage cost paid to the railway by the company. The various reasons of delay due to the RMHS department are Hopper Jamming, Transfer Chute jamming, Wagon cleaning and Common Route Problem, Electrical failures, Mechanical failures and Shift change. In this paper, the Mechanical failure/shutdown problem in the rake unloading process has been discussed in details which happen due to Mechanical Failure of the equipment (Wagon Tippler, Stacker system (TBS) and conveyor belt) in the system. In the following subsections the proposed method has been presented.

\section{Data Collection for Unloading Process}

To accomplish the delay time analysis, data were collected from the RMHS departments (Table 1). The data include total number of rakes received, delay time in unloading process due to mechanical failure of unloading equipments.

Table 1: Delay Time Due to Mechanical Failure of Equipments in the Year 2015-16. (hh:mm)

\begin{tabular}{|c|c|c|c|c|c|c|c|c|c|c|c|c|c|}
\hline Apr & May & June & July & Aug & Sep & Oct & Nov & Dec & Jan & Feb & Mar & Total delay & Total Rake \\
\hline $1: 30$ & $6: 35$ & $9: 15$ & $3: 40$ & $10: 30$ & $12: 25$ & $3: 50$ & $2: 40$ & $6: 00$ & $3: 10$ & $1: 25$ & $9: 50$ & $70: 50$ & 251 \\
\hline
\end{tabular}

\section{Detailed Analysis of the Mechanical Failure}

To identify the basic element of the system which majorly contributes in mechanical failure, at first the mechanical failure of the system has been analyzed and represented using FTA. Fault tree analysis (FTA) is a logical analysis tool with a deductive top down approach that proceeds deductively from the occurrence of an undesired event (failure) to the identification of the root causes of that event.

\section{FTA on Mechanical Failure}

Figure 1, shows some notations used in FTA and Figure 2 shows the FTA carried out on the mechanical failure of the rake unloading system for the identification of the potential root causes of the identified failures

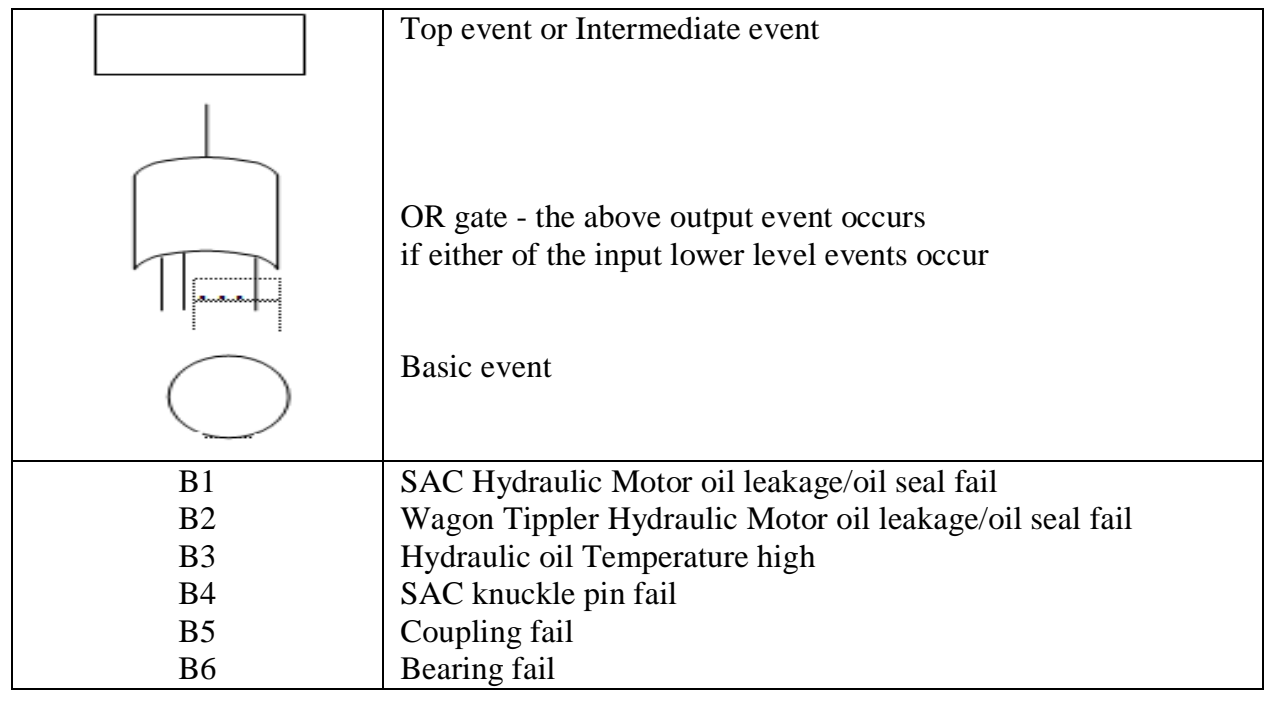




\begin{tabular}{|l|l|}
\hline B7 & Break loose \\
B8 & Cut \\
B9 & Skirt rubber damaged \\
B10 & Bearing fail \\
B11 & Coupling bolts loose \\
\hline
\end{tabular}

Figure 1: Notations Used in FTA

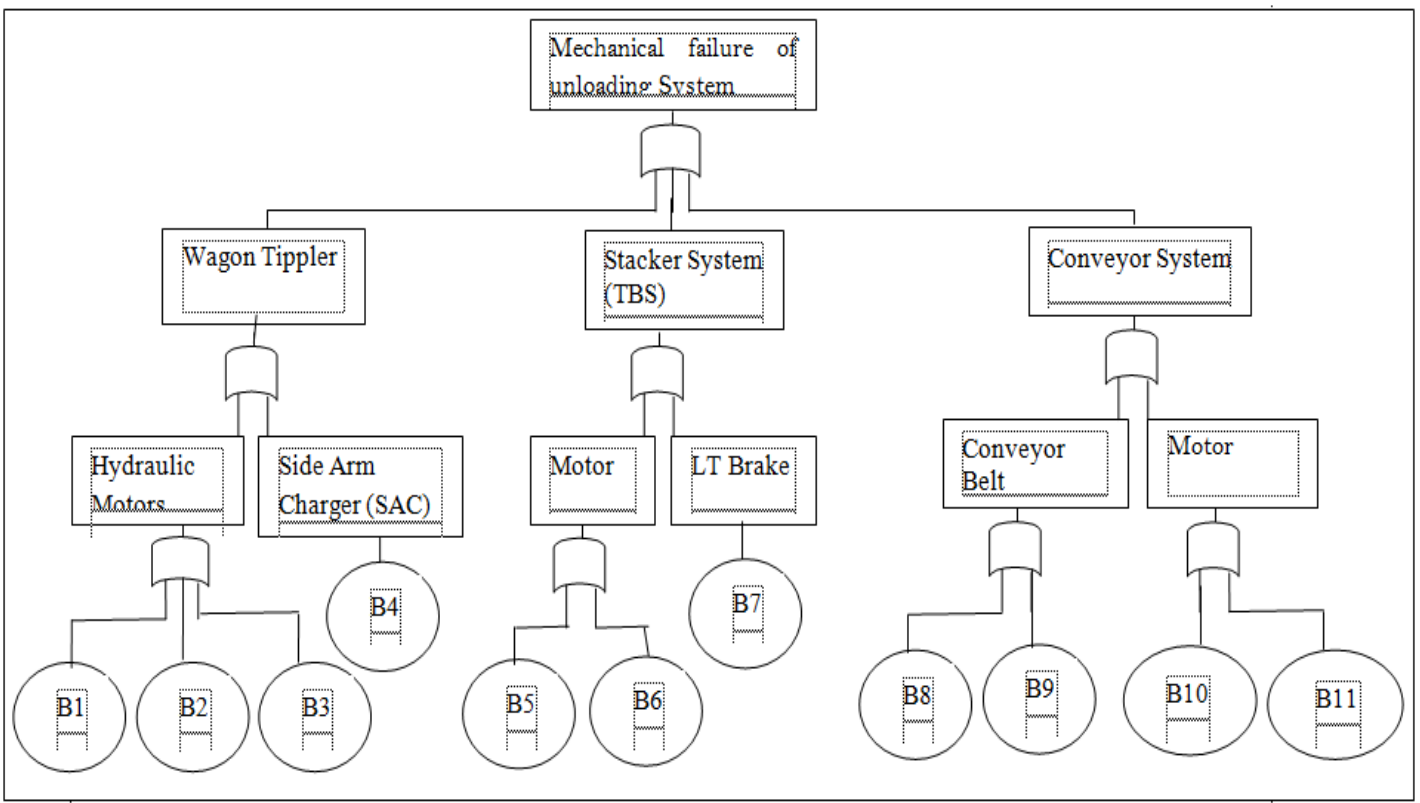

Figure 2: FTA for the Failure of the Rake Unloading Process

After finding the root cause (basic events represented in the circle, B1-B11 in above figure 2) of the failure using FTA, a deep study has been carried out on the system and by using FMECA (Failure mode effect criticality analysis) method, the critical/main element of unloading system has been identified which required proper attention, proper maintenance schedule and sufficient spares, parts inventories of that element so that Failure/shut down time of the rake unloading process will minimize.

\section{FMECA for the Equipments used in the Rake Unloading System}

For this analysis the failure data is generated and collected from the downtime of the equipments used in the unloading process (Wagon Tippler, TBS, and Conveyor belt) for three months. The data contains all the relevant information required for finding the critical cause, such as:

- $\quad$ Type of failure

- Reason of failure

- Component(s) failure

- $\quad$ Frequency of failure

After investigating the data of three months (July 2016 -September 2016), it has been found that total numbers of rake unloaded in the plant premises in these three months containing different raw materials are 74 , the total engaged time of the equipments used in unloading process is 760 hours and total failure time due to different reasons is 41 hours. 
The generated failure data is now analyzed using FMECA to compute the criticality for each failure mode and failed component. It involves the identification of failure modes, cause, effects and criticality of such failures. Each failure mode is classified into several categories based on their severity (Refer Table 2).

Criticality of failure modes is calculated for each of the components and the largest critical component whose $\mathrm{C}_{\mathrm{m}}$ value is largest is found as a focal cause of delay in unloading process due to mechanical failure of the machine.

Table 2: Severity Classification and its Probability Value

\begin{tabular}{|c|l|l|c|}
\hline Category & Classification & \multicolumn{1}{c|}{ Description } & Probability value (f $\mathbf{f}_{\mathbf{s}}$ ) \\
\hline I & Catastrophic & $\begin{array}{l}\text { Major loss occurs: Significant system failure causing } \\
\text { major damage such as loss of life, injury, etc. }\end{array}$ & 1.00 \\
\hline II & Critical & $\begin{array}{l}\text { Complete loss of the system occurs: A failure which } \\
\text { may cause severe injury, major property damage, or } \\
\text { major system damage. }\end{array}$ & 0.75 \\
\hline III & Marginal & $\begin{array}{l}\text { System is degraded: A failure which may cause } \\
\text { minor injury, minor property damage, or minor } \\
\text { system damage which will result in delay or loss of } \\
\text { availability. }\end{array}$ & 0.50 \\
\hline IV & Negligible & $\begin{array}{l}\text { Minor failure occurs: A failure not serious enough to } \\
\text { cause injury, property damage, or system damage, } \\
\text { but it will result in unscheduled maintenance or } \\
\text { repair. }\end{array}$ & 0.25 \\
\hline
\end{tabular}

Table 3: FMECA for the Equipments Used in the Rake Unloading Process

\begin{tabular}{|c|c|c|c|c|c|c|c|}
\hline \multirow[b]{2}{*}{$\begin{array}{c}\text { Basic } \\
\text { Events/Failure } \\
\text { Mode }\end{array}$} & \multirow[b]{2}{*}{$\begin{array}{l}\text { Failure Cause } \\
\text { and Effect }\end{array}$} & \multirow[b]{2}{*}{$\begin{array}{c}\text { Severity } \\
\text { Class } \\
\mathbf{f}_{\mathrm{s}}\end{array}$} & \multicolumn{5}{|c|}{ Parameters of Criticality Index } \\
\hline & & & $\begin{array}{c}\text { Fail } \\
\text { ure } \\
\text { Hou } \\
\mathbf{r} \\
\mathbf{f}_{\mathbf{i}}\end{array}$ & $\begin{array}{c}\text { Failure } \\
\text { Mode } \\
\text { Ratio } \\
\boldsymbol{\alpha}_{\mathrm{i}}=\mathbf{f}_{\mathrm{i}} / \mathbf{f}_{\mathrm{t}}\end{array}$ & $\begin{array}{l}\text { Failure } \\
\text { Rate } \\
\lambda_{\text {pt }}=\mathbf{f}_{\mathrm{i}} / \mathrm{t}\end{array}$ & $\begin{array}{c}\text { Operati } \\
\text { ng } \\
\text { Time } \\
\beta_{i} \times t\end{array}$ & $\begin{array}{c}\text { Failure } \\
\text { Mode } \\
\text { criticality } \\
\mathrm{C}_{\mathrm{m}}=\beta_{\mathrm{i}} \times \boldsymbol{\alpha}_{\mathrm{i}} \\
\times \lambda_{\mathrm{pt}} \times \mathrm{t}\end{array}$ \\
\hline $\begin{array}{l}\text { SAC Hydraulic } \\
\text { Motor oil } \\
\text { leakage/oil seal fail }\end{array}$ & $\begin{array}{l}\text { Wear and tear, loss of } \\
\text { control }\end{array}$ & III, 0.50 & 7 & 0.58 & 0.0092 & 220.4 & 1.18 \\
\hline $\begin{array}{l}\text { Wagon Tippler } \\
\text { Hydraulic Motor oil } \\
\text { leakage/oil seal fail }\end{array}$ & $\begin{array}{l}\text { Wear and tear, loss of } \\
\text { control }\end{array}$ & III, 0.50 & 3 & 0.25 & 0.0039 & 95 & 0.09 \\
\hline $\begin{array}{l}\text { Hydraulic oil } \\
\text { Temperature high }\end{array}$ & $\begin{array}{l}\text { Wear and tear, loss of } \\
\text { control }\end{array}$ & IV, 0.25 & 2 & 0.17 & 0.0026 & 34.2 & 0.02 \\
\hline $\begin{array}{l}\text { SAC knuckle pin } \\
\text { fail }\end{array}$ & $\begin{array}{l}\text { Wear and tear, loss of } \\
\text { control }\end{array}$ & IV, 0.25 & 2 & 1.00 & 0.0026 & 190 & 0.49 \\
\hline Coupling fail & $\begin{array}{l}\text { Wear and tear loss of } \\
\text { control }\end{array}$ & III, 0.50 & 7 & 0.58 & 0.0092 & 220.4 & 1.18 \\
\hline Bearing fail & $\begin{array}{l}\text { Wear and tear loss of } \\
\text { control }\end{array}$ & III, 0.50 & 5 & 0.42 & 0.0066 & 159.6 & 0.44 \\
\hline Break loose & $\begin{array}{l}\text { Wear and tear loss of } \\
\text { control }\end{array}$ & IV, 0.25 & 2 & 1.00 & 0.0026 & 190 & 0.49 \\
\hline Cut & $\begin{array}{l}\text { Wear and tear, loss of } \\
\text { control, cut due to } \\
\text { foreign material }\end{array}$ & III, 0.50 & 6 & 1.00 & 0.0079 & 380 & 1.50 \\
\hline $\begin{array}{l}\text { Skirt rubber } \\
\text { damaged }\end{array}$ & $\begin{array}{l}\text { Wear and tear loss of } \\
\text { control }\end{array}$ & IV, 0.25 & 2 & 1.00 & 0.0026 & 190 & 0.49 \\
\hline Bearing fail & $\begin{array}{l}\text { Wear and tear loss of } \\
\text { control }\end{array}$ & III, 0.50 & 4 & 1.00 & 0.0052 & 380 & 0.99 \\
\hline
\end{tabular}




\begin{tabular}{|l|l|c|c|c|c|c|c|}
\hline \multicolumn{9}{|c|}{ Table 3: Contd., } & IV, 0.25 & 1 & 1.00 & 0.0013 & 190 & 0.25 \\
\hline Coupling bolts loose & $\begin{array}{l}\text { Wear and tear, } \\
\text { increase power } \\
\text { consumption }\end{array}$ & IV &
\end{tabular}

In Table $3, \mathrm{f}_{\mathrm{s}}=$ Probability value of severity, $\mathrm{f}_{\mathrm{i}}=$ Number of failure of components ' $\mathrm{i}$ ', for a particular failure mode, $\mathrm{f}_{\mathrm{t}}=$ Total number of failure used in analysis, $\mathrm{t}=$ Operational time in hours, $\alpha_{\mathrm{i}}=$ Failure ratio mode, $\lambda_{\mathrm{pt}}=$ Part failure rate, $\beta_{\mathrm{i}}=$ conditional probability of loss, $\mathrm{C}_{\mathrm{m}}=$ Failure mode criticality

From Table 3, it can be found that $\mathrm{C}_{\mathrm{m}}=1.5$ is the highest which is for failure mode 'cut' of the component Conveyor Belt of a conveyor system. Hence it is the focal cause of the delay of the rake unloading process if occurs. Moreover, from the Table 3, it can be found that the critical components of the Wagon tippler and Stacker system (TBS) are SAC Hydraulic Motor oil leakage/oil seal fail and coupling fail respectively.

The proper maintenance scheduling is required for the critical components of the failure, such that failures are prevented and the delay time in the rake unloading process is minimized. After studying the system and managerial discussion, it can be found that, to prevent the cut/snap of the conveyor belt, a magnetic separator may be installed which separate the foreign material which causes the cuts/snap in the conveyor belt. However, the work is in an intermediate stage and needs more study.

\section{CONCLUSIONS}

This paper proposes a novel methodology for decision support by failure analysis in the raw materials unloading process. The methodology integrates data collection and exploration that help the management to find out the significant problem in unloading process. The methodology is established using the application case of the railway rakes unloading process data of an integrated steel plant. In the study, after collecting the data from the concerned department, data exploration, FTA and FMECA method have been applied. From the derived critical component of the failure, a management could take precautionary steps to avoid the delay time due to equipment failure. In the future work, the proper maintenance schedule of the critical components using NHPP models may be generated and also the effect of installing the magnetic separator in conveyor system to avoid the cut/snap through foreign materials will be studied.

\section{REFERENCES}

1. Brito, T. B., Silva, R., Botter, R., Pereira, N., Medina, A. (2010). Discrete event simulation combined with multi-criteria decision analysis applied to steel plant logistics system planning. In Proc. 2010 Winter Simulation Conference, 105-132.

2. Mukherjee, S., Jha, A., Kumar, R. (2013). Reduction of Demurrage Cost for Inward Rakes through Material Reallocation in an Integrated Steel \& Power Industry - A Case Study. International Journal in multidisciplinary and Academic Research, 2(2).

3. Abhilasha, D. A., and Mohite, N. Y. (2015). Significance of Selection of Material Handling System Design in Industry - A Review. International Journal of Engineering Research and General Science. 3(2), 76-79.

4. Mukherjee, A., Som, A., Adak, A., Raj, P. (2012). Kirtania S. Augmenting an inbound raw material handling system of a steel plant by uncovering hidden logistics capacity. In Proceedings of the 2012 Winter Simulation Conference, 1-12.

5. Horenbeek, A. V., Ostaeyen, J. V., Duflou, J. R., Pintelon, L. (2013). Quantifying the added value of an imperfectly performing condition monitoring system-application to a wind turbine gearbox. Reliability Engineering \& System Safety, 111(3), 45-57.

6. Yuzukirmizi, M., Arslan, H., Duman, O. (2015). Multivariate Statistical Methods for Detection of Spur Gear Faults. Journal of 
Mechanical Engineering and Science, 229, 2586-2598.

7. Sharma, R. K., Sharma, P. (2010). System failure behavior and maintenance decision making using, RCA, FMEA and FM. Journal of Quality in Maintenance Engineering, 16, 64-88.

8. Srivastava, N. K., Mondal, S. (2016). Development of Predictive Maintenance Model for N-Component Repairable System using NHPP Models and System Availability Concept. Global Business Review, 17(1), 105-115.

9. Srivastava, N. K., Mondal S. (2015). Predictive maintenance using modified FMECA method. International journal of productivity and quality management, 16(3), 266-279.

10. Qiang Z, Haijian W. (2012).Mining machinery system remote monitoring early warning and fault diagnosis. Disaster Advances, 5(4), 1709-1712.

11. Jiang W, Qu F, Zhang L. (2012). Quantitative identification and analysis on hazard sources of roof fall accident in coal mine. Procedia Engineering, 45, 83-88.

12. Ivanovic G, Mitrovic R, Jovanovic D. (2013). Reliability of transportation belt rollers used in surface coal digging. Advanced Materials Research, 633, 312-321. 
